\title{
Activated B-Cell Positive
}

National Cancer Institute

\section{Source}

National Cancer Institute. Activated B-Cell Positive. NCI Thesaurus. Code C142124.

An indication that actively proliferating and differentiating B-lymphocytes have been detected in a sample. 